\title{
Cardiac surgical aspects of Down syndrome
}

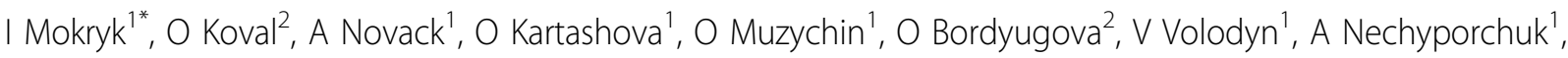 \\ R Klymanskiy', V Konov ${ }^{1}$
}

From 23rd World Congress of the World Society of Cardio-Thoracic Surgeons

Split, Croatia. 12-15 September 2013

\section{Background}

The number of children with Down syndrome (DS) in general population reaches $4,8-7,0 \%$. More than $45,0 \%$ of them have different forms of congenital heart diseases (CHD), which is the main death cause in this patient group under two years of age. The purpose of this study was to analyze details of perioperative period in children with DS undergoing CHD repair.

\section{Methods}

Between 2009 and 2012, 34 consecutive patients with DS and CHD were admitted for medical or surgical treatment. There were $19(56,0 \%)$ boys and $15(44,0 \%)$ girls aged from 4 months to 18 years (20 month \pm 2 month). Most common CHD was AVSD, witch had 16 (47.1\%).

\section{Results}

$82,5 \%(\mathrm{n}=28)$ had hard combined CHD, $82,4 \%(\mathrm{n}=28)$ high pulmonary hypertension, all patients - heart failure. In $20,6 \%(\mathrm{n}=6)$ patients heart catheterization was performed. $6(20,6 \%)$ kids received only medical treatment: $2(5,8 \%)$ - inoperable, $3(8,8 \%)$ medical preparation for surgery due to $\mathrm{PH}, 1(2,9 \%)$ - no need of surgery. $28(82,4 \%)$ patients were operated on. $26(92,8 \%)$ were open heart cases. 57,6\% $(\mathrm{n}=15)$ underwent septal defects (ASD, VSD) plasty at median age of $12 \pm 3$ months. In $42,3 \%$ (n =11) AVSD was corrected at median age of $6 \pm 1$ month. In 7 patients $(23,6 \%)$ postoperative period was complicated by: DIC syndrome $(57,1 \%)$, sepsis $(28,6 \%)$, chylothorax (14,3\%). 30-day in hospital mortality occurred in $3(10,7 \%)$ cases: $1(14,3 \%)$ - due to intractable pulmonary hypertensive crisis; $1(14,3 \%)$ - sepsis; $1(14,3 \%)$ - sepsis associated

\footnotetext{
* Correspondence: mokrykdoc@yahoo.com

'Department of Cardio Surgery, Cardiology and Rehabilitation for Children, Government Institution "Institute of Urgent and Recovery Surgery named after V.K. Gusak National Academy of Medical Science of Ukraine", Donetsk, Ukraine

Full list of author information is available at the end of the article
}

with DIC syndrome. Neither late death nor any residual defects requiring reoperation were detected at follow up.

\section{Conclusions}

Surgical correction of CHD in children with DS can be accomplished with acceptable morbidity and mortality rates. Improvement of medical results is possible with special emphasis on preoperative diagnosis and treatment of complications of CHD (PH) and associated pathology (hematologic disorders, infections and immunity status disorders).

\section{Authors' details}

${ }^{1}$ Department of Cardio Surgery, Cardiology and Rehabilitation for Children, Government Institution "Institute of Urgent and Recovery Surgery named after V.K. Gusak National Academy of Medical Science of Ukraine", Donetsk, Ukraine. ${ }^{2}$ Pediatric Subdepartment of Internship and Postgraduate Education Faculty of Donetsk National Medical University n.a. M. Gorkiy, Donetsk, Ukraine.

Published: 11 September 2013

doi:10.1186/1749-8090-8-S1-P96

Cite this article as: Mokryk et al:: Cardiac surgical aspects of Down syndrome. Journal of Cardiothoracic Surgery 2013 8(Suppl 1):P96.

Submit your next manuscript to BioMed Central and take full advantage of:

- Convenient online submission

- Thorough peer review

- No space constraints or color figure charges

- Immediate publication on acceptance

- Inclusion in PubMed, CAS, Scopus and Google Scholar

- Research which is freely available for redistribution
C Biomed Central

C 2013 Mokryk et al; licensee BioMed Central Ltd. This is an Open Access article distributed under the terms of the Creative Commons Attribution License (http://creativecommons.org/licenses/by/2.0), which permits unrestricted use, distribution, and reproduction in any medium, provided the original work is properly cited. 